\title{
Addressing secondary school students' everyday ideas about freshwater springs in order to develop an instructional tool to promote conceptual reconstruction
}

\author{
S. Reinfried ${ }^{1}$, S. Tempelmann ${ }^{1}$, and U. Aeschbacher ${ }^{2}$ \\ ${ }^{1}$ University of Teacher Education Central Switzerland Lucerne (PHZ), Department of Teaching and Learning, \\ Töpferstrasse 10, 6004 Lucerne, Switzerland \\ ${ }^{2}$ DemoEx Company, Via Lavizzari 2, 6600 Locarno, Switzerland \\ Correspondence to: S. Reinfried (s.reinfried@bluewin.ch)
}

Received: 23 November 2011 - Published in Hydrol. Earth Syst. Sci. Discuss.: 2 February 2012

Revised: 13 April 2012 - Accepted: 24 April 2012 - Published: 10 May 2012

\begin{abstract}
Water knowledge" has now become a sociopolitical and future-orientated necessity. Everyday ideas or preconceptions of hydrology can have a deleterious effect one people's understanding of the scientific facts and their interrelations that are of relevance to sustainable water management. This explorative pilot study shows that preconceived notions about the origin of freshwater springs are common at the lower secondary school level. The purpose of this study was two-fold: (1) to investigate the nature of everyday ideas about freshwater springs among 81 13-yr-old Swiss students, and (2) to develop an efficient instructional tool that promotes conceptual reconstruction in the learners' minds. To assess students' everyday ideas we conducted interviews, examined student work, and asked students to fill in a questionnaire. The results indicate that half of the students have some basic hydrological knowledge. However, several preconceived notions that can significantly impede the understanding of hydrological concepts have been found. A common preconception concerns the idea that solid rocks cannot be permeable and that large underground cavities constitute a necessary precondition for the formation of springs. While these ideas may well be true for karst springs they inhibit the understanding of the concept of other spring types due to their plausibility and intelligibility. We therefore chose the concept of the hillslope spring to construct an instructional tool that takes into account the findings of the psychology of learning aimed at promoting deep learning, thus facilitating a lasting conceptual reconstruction of the concept of springs.
\end{abstract}

\section{Introduction}

Springs form an interface between underground and surface subsystems of the hydrological cycle and represent nodal points between the nature system and the human system. Water springs are important resources of drinking water, aesthetic elements of the landscape and significant habitats for fauna and flora. However, springs now largely elude our sensory perception and experience. A survey among 749 adults showed that almost two thirds of them had never seen a natural spring (Suter et al., 2007). $70 \%$ of respondents were unable to specify a causal relationship between springs and the water taps in their homes, even when springs played a role in the supply of drinking water within their local community. This is hardly surprising; after all, the steadily increasing total consumption of clean drinking water has resulted in the capture of more and more springs. In the densely populated Swiss Plateau region for instance, the proportion of captured or culverted springs has risen over the past $100 \mathrm{yr}$ from $64 \%$ (1884) to $94 \%$ (1990). Over the same period in the less densely populated Swiss Jura Mountains almost three quarters of free-flowing springs have disappeared (Zollhöfer, 1999). Springs are also being directly affected at their magnitude of discharge as a result of increasing interference in nature, for instance through infrastructure measures (Krummenacher, 2007; Regli, 2009). Climate change is also expected to have a far-reaching impact on springs, with fears of a warming of the groundwater (Denzler, 2009) and a lowering of the groundwater table (Koechlin, 2011). 
A better understanding of springs as a resource is therefore urgently needed; indeed, a more careful handling of springs can only be achieved if knowledge of the fact that springs and their catchment areas are sensitive and vulnerable systems is anchored in all citizens' minds. Understanding complex science concepts related to environmental education, such as springs, pertains to scientific literacy. People who dispose of in-depth knowledge of scientific concepts are able to participate in discussions concerning environmental problems and to take responsible action. The fact that the term "spring water" has positive connotations (Suter et al., 2007) as reflected in brand names for bottled water such as natural spring water or mountain spring water, is a good starting point to tackle the problem. The water cycle is part of the curriculum in grade 7 in Swiss secondary schools but the topic of freshwater springs is not explicitly included (Reinfried, 2001). In fact, there is very little suitable teaching material on the hydrological cycle as well as on springs. Our research on school textbooks showed that the teaching of hydrological knowledge over the period of compulsory education is limited mostly to highly abstract representations of the hydrological cycle. That knowledge is not sufficient to provide an understanding of the complex hydrological connections within the earth system and the particular role played by springs within that system.

Former studies investigating students' everyday ideas of hydrological concepts revealed various preconceptions and misconceptions, also about freshwater springs (see Sect. 2). These findings were in accordance with educational research that has shown that students, regardless of their age, come to class with personal ideas about scientific concepts (Vosniadou, 2008). Since such personal ideas are mostly erroneous and not consistent with the scientific understanding of the concepts, they can actually impede correct understanding of the scientific concepts during learning. Therefore, the learners' everyday ideas and misunderstandings must be taken into account when designing teaching material and learning environments aimed at conceptional development and indepth understanding.

The current paper presents an exploratory pilot study investigating the nature of preconceived notions and misconceptions about freshwater springs among 13-yr-old students. It further describes the development of an efficient instructional tool to promote conceptual reconstruction in the learners' minds by taking into account their everyday ideas about freshwater springs. By describing in detail the learners' preconceptions on this topic we intend to demonstrate why it is necessary to know about the learners' prior knowledge in order to be able to trigger in-depth learning processes. Before introducing the study, we present a brief overview of previous research on learners' conceptions of hydrological concepts, particularly of freshwater springs, and explain why it is important for instructors to know the preconceptions of their learners.

\section{Everyday notions and hydrological learning}

Various studies demonstrate that the understanding of hydrological processes among both children and adults is patchy and mistaken. Erroneous everyday notions or preconceptions of hydrology concern all subareas of the hydrological cycle, i.e. evaporation, condensation, precipitation, underground and surface run-off, springs, as well as knowledge of the connection between catchment areas and water courses, and water management (e.g. Bar, 1989; Ben-zvi-Assarf and Orion, 2005; Chang, 1999; Dickerson and Dawkins, 2004; Dickerson et al., 2005; Dove, 1998; Dove et al., 1999; Österlind and Halldén, 2007; Reinfried, 2006a, b; Shepardson et al., 2009). Evaporation and condensation as well as the occurrence of groundwater and the causes that lead to the formation of springs are complex, abstract concepts which, to the layman, are not immediately clear. Even when hydrological phenomena become visible, such as a "steaming" lake or the fluctuating flow of a spring, they cannot be readily explained without technical knowledge. As part of a study on everyday ideas about groundwater Reinfried (2006a, b) noted that secondary school students and teacher training students often imagined springs as "pipes" branching off from groundwater "arteries". In a representative survey carried out in the Basel region Suter et al. (2007, p. 8) were able to show that idealised notions of springs are commonplace in society. The term spring is generally linked with positive associations within the population. Spring water is regarded as being of better quality than groundwater (Suter et al., 2007), even though spring water and groundwater are essentially the same substance and spring water in karst regions can be contaminated (Auckenthaler and Huggenberger, 2003). Notionally, springs are very often linked with the life experience of holidays and leisure and only rarely with the supply of drinking water in everyday life. The occurrences of springs are associated with forests and unspoilt nature, which automatically also entails spring water of a good quality (Suter et al., 2007).

If a basic knowledge of hydrology is to be understood by the learners, lastingly retained and applied to more complex hydrological contexts, the everyday notions of learners need to be taken into account when compiling teaching material and also during lessons. While this is not a new finding, it is still not sufficiently taken into account in teaching practice. The constructivist theory of learning is based on the assumption that learning is the active construction of knowledge and that previous knowledge and previous experience play an important role (Glasersfeld, 1989; Piaget, 1972; Piaget and Cook, 1975; Vygotsky, 1962, 1978). In scientific matters young learners are lay persons whose previous knowledge of science differs considerably from scientific findings, theories and principles. Their previous knowledge consists of pre-instructional notions also referred to as naïve theories (McCloskey, 1983), alternative conceptions, preconceptions (Clement, 1982), misconceptions (Brown and Clement, 
1989) or mental models (Johnson-Laird, 1983) which have been formed in everyday life based on their own observations, information gained from written and electronic media, from peers and adults, and are based on the interpretation of all these observations and information (Vosniadou et al., 2008). These pre-instructional ideas can hamper or impede their understanding of scientific concepts. They are often persistent and difficult to change. To the learner, intuitive previous knowledge is subjectively correct, as it has often proved itself in everyday life.

Pre-instructional notions are the points on which all further knowledge is based (Ausubel, 1968; Duit and Treagust, 2003). They provide the interpretation schemes with which learners interpret everything that is said and shown in lessons. So erroneous ideas in the way learners think cannot simply be replaced with correct technical knowledge; rather, they need to be mentally re-organised by the learner and adapted step by step to the scientific theories. Various studies have shown that lessons which incorporate everyday notions are more successful (Häussler et al., 1998; Reinfried et al., 2010; Wiesner, 1995). When learning opportunities are designed in such a way as to consider the reasoning steps necessary for the learners' understanding and thus enable deep inner learning as defined by educational constructivism, they stimulate understanding-based knowledge construction and a problem-solving way of thinking (Messner and Reusser, 2006). They help learners to adapt their interpretation schemes or develop new ones. With regard specifically to the subject of springs, no systematic surveys have been made to date on the subjective theories of lay persons. For this reason teaching methodology has lacked the elementary basics for developing learning material that builds on the findings of the psychology of learning. The lack of theorybased teaching material means that many people leave school with considerable gaps in their basic knowledge of hydrology. It means that as ordinary citizens they are usually only able to explain hydrological events on the basis of their everyday notions.

\section{Research questions and sample}

\subsection{Objectives of the study}

We are not aware of any study which has systematically examined the everyday ideas of young learners about springs and how they are formed; nor are we aware of any learning material that addresses the topic of springs and is founded on the psychology of learning. This pilot study aims to make good both of these shortcomings. The first phase of the study explored and recorded the everyday ideas that 13 -yr-old students have of springs and how they are formed, and examined their characteristics. In the second phase, the study followed an instructional goal: building on the findings gained about everyday ideas, an instructional tool was developed based on the psychology of learning. The learning tool readily illustrates the processes involved in the formation of springs in such a way as to build up near-scientific notions, modify misconceptions, and help to better understand and retain the new knowledge.

\subsection{Participants}

The participants, a convenience sample, comprised 81 students (47 girls and 34 boys) at the lower secondary school level (7th grade) from the Cantons of Zurich, Zug and Lucerne. The students' average age was $13.1 \mathrm{yr}$ (SD 0.7). All 81 test persons were asked to complete a questionnaire with knowledge-based questions. Almost all of them, i.e. 80 respondents, also made a drawing of their ideas of springs and gave a written description of the drawing. After an initial evaluation of the questionnaires and drawings 10 individuals (7 girls and 3 boys) from the group of students from the Canton of Zurich were picked for an interview. They were chosen because they showed either very typical or particularly striking ideas about springs.

\section{Methodology and instruments}

\subsection{Analysis of the students' ideas}

The students' ideas about springs were analysed using a questionnaire, the students' drawings and texts, and interviews (see Sect. 4.2). Due to the exploratory character of this study the data acquired was evaluated using various methods. Qualitative methods (structuring content analysis) were used to analyse the drawings and texts and one open questionnaire item (Q4; see Sect. 4.2.2); quantitative methods (descriptive statistics) were used to analyse the closed questionnaire items and the quantifiable categories generated from the drawings. The purpose of using this combination of research methodologies (methodological triangulation) to explore the students' ideas was to increase the validity of the results.

\subsection{Instruments}

\subsubsection{Closed questionnaire items}

The questionnaire was used to record the learners' knowledge of freshwater springs and how they are formed. The questionnaire consisted of 28 knowledge-based questions. Eleven selected questionnaire items are reproduced in Table 1 . The nature of the questions was explorative. They were designed to allow an insight into the knowledge and preconceptions of 13-yr-old schoolchildren on the subject of springs. The questions were based on research on springs and ideas of springs in specialist and popular science literature (Baumgartner and Liebscher, 1990; Baur, 1989; Göbel, 2007; Hölting and Coldewey, 2009; Tarbuck and Lutgens, 2009), children's books (Hass et al., 2004; Sanchez, 1977; 
Table 1. Students' replies to selected questionnaire items.

\begin{tabular}{|c|c|c|c|c|}
\hline \multirow{2}{*}{ Category } & \multirow{2}{*}{ Questionnaire Item } & \multicolumn{3}{|c|}{ Reply } \\
\hline & & agree & neutral & disagree \\
\hline \multirow{5}{*}{$\begin{array}{l}\text { Underground } \\
\text { processes and } \\
\text { structures }\end{array}$} & $\begin{array}{l}\text { A spring occurs wherever groundwater } \\
\text { emerges from the ground. }\end{array}$ & $65.0 \%$ & $27.5 \%$ & $7.5 \%$ \\
\hline & $\begin{array}{l}\text { Springs occur as a result of water-retaining } \\
\text { rock layers. }\end{array}$ & $11.4 \%$ & $72.2 \%$ & $16.5 \%$ \\
\hline & $\begin{array}{l}\text { A spring is the end of an underground } \\
\text { water vein. }\end{array}$ & $48.1 \%$ & $43.2 \%$ & $8.6 \%$ \\
\hline & $\begin{array}{l}\text { Springs occur wherever an aquiferous layer } \\
\text { of rock outcrops at the surface. }\end{array}$ & $30.8 \%$ & $62.8 \%$ & $6.4 \%$ \\
\hline & $\begin{array}{l}\text { A spring is a place where an entire stream } \\
\text { emerges out of the ground or a rock face. }\end{array}$ & $29.6 \%$ & $42.0 \%$ & $28.4 \%$ \\
\hline $\begin{array}{l}\text { Origin of spring } \\
\text { water }\end{array}$ & $\begin{array}{l}\text { Springs can dry out if it does not rain for } \\
\text { several weeks. }\end{array}$ & $52.6 \%$ & $30.8 \%$ & $16.7 \%$ \\
\hline \multirow[t]{2}{*}{$\begin{array}{l}\text { Spring water } \\
\text { discharge }\end{array}$} & $\begin{array}{l}\text { Spring water is pressed to the surface by the } \\
\text { pressure of the layers of rock above it. }\end{array}$ & $41.3 \%$ & $47.5 \%$ & $11.3 \%$ \\
\hline & $\begin{array}{l}\text { Springs are always located high up in } \\
\text { the mountains. }\end{array}$ & $22.5 \%$ & $46.3 \%$ & $31.3 \%$ \\
\hline \multirow{3}{*}{$\begin{array}{l}\text { Water quality/ } \\
\text { filtering }\end{array}$} & Springs always produce clean water. & $54.4 \%$ & $30.4 \%$ & $15.2 \%$ \\
\hline & Springs always produce clear water. & $55.1 \%$ & $38.5 \%$ & $6.4 \%$ \\
\hline & Spring water is healthier than tap water. & $63.3 \%$ & $31.6 \%$ & $5.1 \%$ \\
\hline
\end{tabular}

Schmidt, 1989), and discussions with four experts: a geographer, a hydrologist, an ecologist and a science didactician. The closed questions were taken from four topic areas: the origin of springs, the occurrence of springs in nature, the water quality of springs, and the mythology of springs. Answers to the 28 questionnaire items were based on a 5-point Likert scale ranging from "strongly disagree" (Position 1) to "strongly agree" (Position 5). Ticking Positions 1 and 2 implied a refusal; Position 3, a neutral reply; and Positions 4 and 5, an affirmative reply. An additional column was also provided for "don't know" replies. This concept prevented "missing values" in terms of statistical evaluation. With regard to the exploratory nature of the questionnaire we evaluated each of the closed questions individually. The quantitative analysis was carried out using SPSS/PAWS.

\subsubsection{Drawings and texts}

The students' were also asked to draw and describe their ideas about springs. A system of categories was inductively developed (see Table 2) to analyse the 80 drawings and texts and the replies to the open question Q4 ("How do you explain that spring water flows out of the ground or a rock face? What might this be due to?"). To test the reliability of the category system, roughly $20 \%$ of the drawing material was evaluated by a second rater and the inter-rater reliability determined using Cohen's Kappa. Only categories with a minimum value of $k=0.61$ were taken into account in the evaluation, corresponding to a "good" to "very good" strength of inter-rater reliability (Altman, 1991). The categorisation was followed by a descriptive evaluation of the data using SPSS/PAWS and Excel.

\subsubsection{Structured interviews}

Interviews were used to explore in greater depth typical and particularly striking ideas about springs and how they are formed, ideas previously identified using the analyses. For each learner interviewed, an individual semi-structured guideline interview was compiled, tailored specifically to his or her typical ideas. Each interview lasted approx. $10 \mathrm{~min}$ and was audio recorded. The recordings were transcribed using F4 computer software. The interview protocols were then evaluated qualitatively. The MAXQDA program was used for coding; the methodology used was structuring content analysis according to Mayring (2008).

\section{Results of the analysis of the students' ideas}

The results of the quantitative analysis of the questionnaire items and of the structuring content analysis of the students' drawings and interviews are described in the following sections in linked form (see also Tables 1 and 2). We have only referred to those questionnaire items that provided information of relevance to the students' ideas identified as part of the methodological triangulation. 
Table 2. Frequency of the subcategories identified in the students' drawings and in the students' answers to the item Q4 (see Sect. 5.3) related to the total sample $(n=80)$ in percentage values (absolute figures in brackets); several subcategories may occur simultaneously in one and the same drawing.

\begin{tabular}{llrc}
\hline Categories & Subcategories & Frequencies \\
\hline Underground processes & Underground processes are assumed in principle & $80.0 \%$ & $(64)$ \\
and structures & Underground processes are illustrated & $65.0 \%$ & $(52)$ \\
& Structured earth's crust is illustrated & $3.8 \%$ & $(3)$ \\
& Impermeable stratum is illustrated & $1.3 \%$ & $(1)$ \\
& Water is present in channels or veins & $17.5 \%$ & $(14)$ \\
& Water is present in gaseous form & $1.3 \%$ & $(1)$ \\
& Water is present in caves & $3.8 \%$ & $(3)$ \\
& Water is present in bladder-like structures & $7.5 \%$ & $(6)$ \\
& Non-specific details about the presence of water & $40.0 \%$ & $(32)$ \\
\hline Origin of spring water & Percolating surface water & $42.5 \%$ & $(34)$ \\
Water discharge & Spring source emerges on a slope & $61.3 \%$ & $(49)$ \\
& Water flowing horizontally or in an oblique angle upwards to the spring source & $45.0 \%$ & $(36)$ \\
& Water flowing vertically upwards to the spring source & $26.3 \%$ & $(21)$ \\
& Subsurface water drainage that follows gravitation & $15.0 \%$ & $(12)$ \\
\hline Causes of water & No causal explanation & $49.4 \%$ & $(40)$ \\
discharge (Q4) & Unspecified pressure & $(17)$ \\
& Pressure from tectonic activity, erosion, etc. & $20.9 \%$ & $(8)$ \\
& Pressure due to inflowing water & $9.8 \%$ & $(8)$ \\
& Specific properties of the water & $4.9 \%$ & $(4)$ \\
& Good quality is mentioned explicitly & $12.3 \%$ & $(10)$ \\
\hline Water quality & & $6.3 \%$ & $(5)$ \\
\hline
\end{tabular}

\subsection{Underground processes and structures}

In connection with springs $20 \%$ of the schoolchildren who made a drawing assumed purely superficial processes; i.e. for them, springs are formed in connection with the surface runoff of water, e.g. rain or melt water. They did not address any of the processes taking place below the surface of the earth; instead, they depicted springs in a purely phenomenological way. Student $201 \mathrm{~F}$ for example drew a glacier, with water flowing downhill, off its surface. In the in-depth interview she explained: "A spring is the melt water that's running out of a glacier". She said that while water did occur underground, it had to be pumped upwards if it was to reach the surface. She was totally unaware of the concept of underground water emerging by itself. By contrast $80 \%$ of learners assumed that there were processes at work below ground that had something to do with springs. This illustrated the answers to the question, "A spring occurs wherever groundwater emerges from the ground", which $65 \%$ of the schoolchildren answered approvingly. $65 \%$ of the students also depicted underground water-related processes in their drawings, e.g. in the form of signatures which filled out the entire subsurface area depicted or in the form of unstructured water layers. Only $3.8 \%$ of learners drew a somehow structured underground area, and of these only one individual drew a simple layered cross section with an impermeable stratum. The questionnaire item "Springs occur as a result of water-retaining rock layers" was answered in the affirmative by only nine schoolchildren (11.4\%). 24 individuals $(30.8 \%)$ answered "Yes" to the item "Springs occur wherever an aquiferous layer of rock outcrops at the surface". The answers to the questions show that many students did have some basic hydrological knowledge. Of the $65 \%$ of schoolchildren who explicitly mentioned underground water resources in their drawings, $40 \%$ did not specify how that water occurred. Student $051 \mathrm{~F}$ assumed that the groundwater evaporated subterraneously and was then present underground in gaseous form. In the interview the student said that the groundwater occurred underground in flowing waters and then evaporated as a result of sunlight heating the mountains. This water vapour rose and condensed inside a chamber, from which the water then flowed out as a stream. $17.5 \%$ of the learners indicated that the underground water occurred in a sort of channelling system, e.g. in a canal or in veins. The students interviewed on this subject gave different responses regarding the origins of these canals. Student $021 \mathrm{~F}$ explained in the interview that the water underground created its own sort of permanent canal system with different hierarchies of ramifications, and did so by displacing earth material. By contrast student $111 \mathrm{G}$ assumed that the water made use of existing underground flow paths and only partly created new structures. Three schoolchildren (3.8\%) assumed that the water was stored in underground caves; six learners $(7.5 \%)$ imagined underground water resources in a 
structure very similar to the human bladder, at least anatomically if not functionally, i.e. an enclosed space completely filled with water, with a canal running to the point of emergence on the earth's surface $(041 \mathrm{~F})$. In the interview student $041 \mathrm{~F}$ explained that the water collects at an impermeable stratum, forming a bladder. The inflowing water creates pressure which causes a vertically rising canal to form and allows the water to run off (see Fig. 1). Student 031F, who drew water rising vertically from a "groundwater stream" (see Fig. 2), construed an analogy with a geyser, even though she had no explanation for the forces responsible for the water's vertical rise.

\subsection{Origin of the spring water}

The questionnaire item "Springs can dry out if it does not rain for several weeks" was answered in the affirmative by $52.6 \%$ of the schoolchildren. That means that half of the students assumed a direct relation between rainfall and the discharge of water from springs. Surprisingly, only $42.5 \%$ of the teenagers addressed the fact that spring water consisted of percolating surface water in their drawings. However, two students who in their drawings did not depict surface water percolating had this to say in their interview, in response to the question about the origin of underground water: "Probably rainwater or something, which has collected in the earth" (student 101G). This shows that some of the students knew more than they expressed in their drawings. One can deduce from $14 \%$ of the drawings that percolating surface water consists of melt water; in $34.8 \%$ of the drawings it consists of rainwater; and in five cases $(6.3 \%)$ it consists of both melt and rainwater.

\subsection{Spring water discharge}

The survey also provided various indications about the students' ideas concerning the origin of a spring, the path taken by the groundwater to the point of emergence, and what causes spring water to discharge in the way it does. $61.3 \%$ of students indicated that spring water emerges on a hillside. $31.3 \%$ of the schoolchildren did not agree with the statement "Springs are always located high up in the mountains". 36 drawings ( $45 \%$ ) were indicative of the direction from which the groundwater reached the point of emergence. It flowed either horizontally underground or rose towards the point at which the spring discharges. In $26.3 \%$ of these drawings the water even flowed vertically upwards, to emerge at the point of intersection with the earth's surface. Two students interviewed about this fact gave very different reasons for this rise. Student 041F (see "bladder idea" in Sect. 5.1) thought that more and more water from percolation processes collected in the underground bladder. He believed that this created pressure and that the water then escaped through a channel that formed wherever the water encounters the least resistance. The student was unable to give a plausible explanation

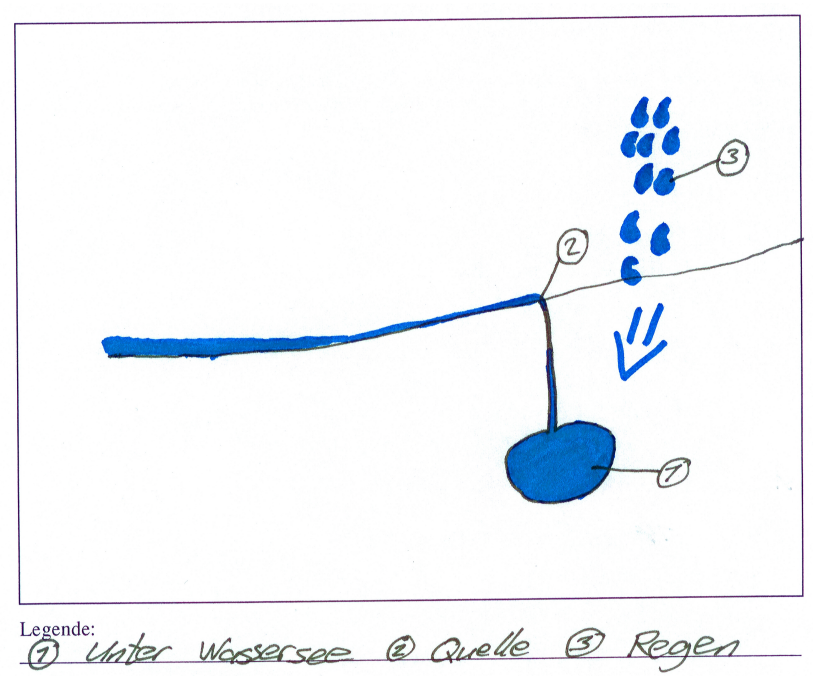

Fig. 1. Drawing of student $041 \mathrm{~F}$ (boy, $14 \mathrm{yr}$ old). Legend: $1=\operatorname{sub}($ terranean) lake, $2=$ spring, $3=$ rain.

of how it was possible for such excess pressure to occur in the bladder in the first place. Student 031F thought that the underground water was somehow "pumped" upwards, to the surface but could not explain how this happened. Only two students $(15 \%)$ drew underground water flows that followed gravitation. $41.3 \%$ agreed with the statement that "Spring water is pressed to the surface by the pressure of the layers of rock above it". In response to the separate open question Q4 "How do you explain that spring water flows out of the ground or out of a rock face? What might this be due to?", almost half the students could not provide any statement or any unambiguously interpretable statement establishing a causal relationship with the reasons for the emerging water. 17 teenagers $(20.9 \%)$ assumed that the emerging water was caused by unspecified pressure, which they were unable to describe in more detail.

22 learners $(27 \%)$ gave explanations relating to all kinds of natural phenomena. For example eight schoolchildren $(9.8 \%)$ assumed that movements of the earth's crust might be the cause. Examples of answers include: "Plates are shifted during earthquakes" (011F) or "Collapsing rock; rocks pressing together" (both 101G). In the interview, student $091 \mathrm{~F}$ said that the earth's rotation caused rocks to move, compressing an underground lake and causing the water to rise to the surface. The erosion of the earth's surface was also assumed to be a cause (091F). Four schoolchildren $(4.9 \%)$ believed that the water was forced out due to the pressure caused by the constant inflow of water. For student $041 \mathrm{~F}$ this mechanism even resulted in a vertical rise of the water, i.e. a movement contrary to gravitation (Fig. 1).

Students $051 \mathrm{~F}$ and $111 \mathrm{G}$ even imagined that atmospheric pressure forced the water out of the mountain while student $201 \mathrm{~F}$ thought global warming was responsible for the 


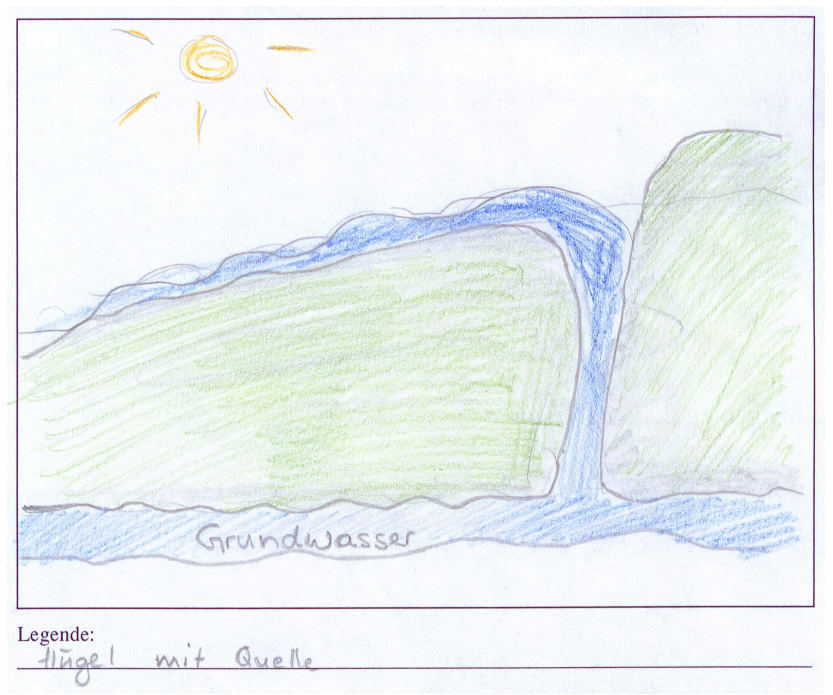

Fig. 2. Drawing of student $031 \mathrm{~F}$ (girl, $13 \mathrm{yr}$ old). Label in the drawing $=$ ground water; legend $=$ hill with a spring.

discharge of water. Ten learners $(12.3 \%)$ explained the causes of the water discharge with notions that the water acted with purpose, e.g. "the water bores its way through" or "the water finds it way". In the case of student 07R, the description given even implied a teleological understanding of water. His statement to the effect that "The water wants to get out of the mountain/out of the ground. So it rises until it finds an opening and then escapes there" reveals a notion of water as an agent pursuing a particular objective.

\subsection{Water quality}

A total of five schoolchildren $(6.3 \%)$ addressed the subject of the good quality of spring water in their drawings. Student $171 \mathrm{G}$ for instance wrote: "I find spring water tasty". This evaluation becomes much clearer still when the questionnaire item to which it relates is considered: only $15.2 \%$ of students rejected the statement "Springs always produce clean water"; and only $6.4 \%$ rejected the item "Springs always produce clear water" while $55.1 \%$ agreed with it. Only four schoolchildren (5.1\%) agreed with the statement that spring water was not generally healthier than tap water. Asked about this, student $191 \mathrm{~F}$ stated that the water was cleaned by the stones through which it percolated ("like a sieve"). He explained that the stones themselves were clean because they in turn had been cleaned by water that had previously filtered through.

\section{Discussion}

One of the aims of the study was to compile 13-yr-old students' ideas about water springs and how they occur, and to find out more about what characterises these ideas. The results indicate that half of the students have already grasped some basic ideas related to the hydrological cycle in their lessons in primary schools. However, the content related structuring of the data further indicates that the answers given in the questionnaire are not based on a fundamental understanding of hydrologic processes that lead to the occurrence of springs. This is not surprising when considering the fact that 7 th graders do not yet have any formal education in earth science in Switzerland. They do not know much about the geological structure of the underlying rocks and the relations between spring water and the hydrological cycle. They also dispose of widespread erroneous ideas about the occurrence of groundwater in the earth's crust and the reasons why it flows and emerges. In a spatial context springs are perceived as very confined phenomena. As far as spring water quality is concerned, the idea that spring water is clean and pure as a principle is common. So any learning material that takes account of the students' ideas must first of all describe a spring as a point at which surface water that has percolated through the ground once again reaches the surface. The simplest case, that of the hillslope spring, is well suited as a model for constructing a near-scientific idea of springs, as it is the one most likely to be associated with the learners' own early childhood experiences when playing in a sandpit. By hillslope spring we understand a spring type that is formed by water soaking into the ground and percolating downward into a porous and permeable layer of a sedimentary rock until the water encounters an impermeable stratum. This layer blocks the downward movement of the groundwater and forces the water to move laterally. Where the permeable bed outcrops, a hillslope spring results.

From the example of the hillslope spring, students can learn how surface, ground and spring water are interconnected; that there are permeable and impermeable rock strata; that water can be stored in loose clastic sediment or in clastic sedimentary rock; how and why it flows underground; and that it can be contaminated by pollutants from the earth surface. The broader spatial perspective of the catchment area should only be addressed once these fundamental notions are understood.

The subjective theories expressed by the learners are intuitive attempts to grasp the natural phenomenon of springs that have been known since the natural philosophy of the Ancient Greeks. A mythological notion encountered in the course of the survey, one that goes back to Greek antiquity, is that, due to rock fall events in mountain areas, sharp fragments of rock strike water veins in the ground, causing springs to well up at those points $(211 \mathrm{~F})$. Theories of natural philosophy that were widespread from Greek antiquity to the modern era were often encountered in this survey. For instance the idea held by student $051 \mathrm{~F}$ that water vapour rises inside a mountain, condenses and becomes spring water, corresponds to the infiltration theory that dates back to Aristotle. The idea that water is stored in vast chambers underground is a theory that was held at least $500 \mathrm{BC}$, by analogy with Mediterranean karst. The 
use of anthropomorphisms such as water veins or bladders inside the body of the earth, whose function resembles those of veins or the bladder in the human body, can already be found in Seneca (Garbrecht, 1990). The similarity between the students' everyday ideas and those of the Ancient Greeks suggests that these ideas are explanatory models that come to mind naturally to people who have little or only restricted scientific background knowledge.

So which of the analysed preconceptions should we now use to convey complementary knowledge in such a way that a conceptual reconstruction can be achieved with the aid of the appropriate learning material? We should address:

- The preconception that groundwater resources only occur in large underground chambers. The learning process should introduce a change of perspective with regard to scale, from large to microscopic scale.

- The preconception that solid rock cannot as a matter of principle be penetrated by water. The learning process can pick up from the everyday experience that loose sediment such as sand or gravel is permeable, and transfer that experience to clastic sedimentary rocks.

- The uncertainty about the fact that springs are part of the hydrological cycle. The learning process needs to illustrate the interconnections that exist between precipitation, percolating surface water and springs. In terms of environmental education this aspect is of great importance for the understanding of spring water contamination and of influences connected with global warming.

- The notion that spring water is of good quality as a matter of principle. The learning process should show that output always depends on input, in other words that springs are affected to varying degrees by environmental factors depending on their geological starting point. This realisation is closely linked with the understanding of springs as part of the hydrological cycle.

- The notion that water rises to the surface through a pressure or force inherent to water as a substance - sometimes, counter-intuitively, against the force of gravity. The learning process is about understanding that the process that leads to the formation of springs first and foremost has to do with precipitation percolating through porous and permeable loose sediment or sedimentary rock, gravitation, blocking by impermeable beds, and the cutting of the aquifer on a hillside; i.e. that the process of spring discharge is a multi-dimensional and complex one, and that a whole array of different factors plays a role.

\section{Learning hydrological concepts through conceptual reconstruction}

So how does one go about changing everyday ideas? Learning is not just about the switch from incorrect to correct concepts during which erroneous ideas simply disappear. Rather, many everyday ideas are retained even after learning and continue to be applied in everyday life. The constructivist approach views learning either as the reconstruction of previous knowledge or the active built-up of knowledge as a new construction in the learner's mind (Kattmann et al., 1997). Accordingly, the students' conceptions and frames of interpretation must by all means be taken into account if deep learning and understanding is to be attained. The science content structure cannot simply be transferred into science instruction in secondary schools, not even in a somewhat simplified manner. Consequently, the content structure of science instruction has to be constructed based on an analysis of the educational significance of the content and on the students' pre-instructional ideas.

To emphasize the perspective that learning involves cognitive constructive activity and that learning is not just an exchange of ideas we use the term conceptual reconstruction (instead of the term conceptual change). Conceptual reconstruction can be facilitated by learning materials aimed at promoting active cognitive learning in order to achieve deep understanding (Reinfried et al., 2012). According to constructivist theories of learning, active learning occurs when learners engage in appropriate cognitive processing during learning, resulting in the construction of cognitive representations (Mayer, 2009; Messner and Reusser, 2006). In this context, key questions that concern conceptual reconstruction are: How should learning material be structured to stimulate focused in-depth learning processes in the learners? How should it be designed to create conditions for inner, non-visible constructivist activities, namely the mental operations the learners should adopt? To answer these questions we turned to the psychological didactics proposed by Hans Aebli, the Swiss psychologist and educator and disciple of Piaget.

Aebli's vision of how learning works is rooted in the classic cognitive constructivist theory of Piaget (1970), specifically in schema construction. Hans Aebli applied Piaget's position of genetic constructivism in practice in the form of a socio-constructivist teaching methodology that he referred to as psychological didactics (Aebli, 1983). The special characteristic of this approach is that it combines the findings of the psychology of learning and the methodology of learning complex science concepts. To Aebli, constructivist teaching means first of all to perceive processes of understanding, learning and thinking from the perspective of the learners, and then to teach accordingly in order to enable the learners to build up their knowledge. His approach aims at activating students cognitively, i.e. to encourage them to construct structures of independent thinking so that they will 
eventually have at their disposal appropriate and useful mental models consisting of a well-organized body of knowledge as well as the underlying methods and strategies of thinking.

Aebli's constructivist approach implies that an abstract concept needs to be broken down into its key steps or basic elements or processes. These units should be comprehensible on the basis of everyday knowledge, respectively be consistent with common assimilation schemata. If the basic elements that constitute a concept are thought through independently in an abstract way, Aebli (1983) talks of "mental operations". Understanding the concept of freshwater springs therefore entails mentally relating an appropriate framework of such operations to the spring concept and its implications and to mentally view the structure of this framework.

\section{Conception of a worksheet on hillslope springs based on the psychology of learning}

In accordance with Aebli's approach (1983) of active cognitive learning aimed at constructing comprehension-oriented knowledge we designed an instructional tool, a worksheet for 7th grade students who had no prior science education (Fig. 3). To ensure that the instructional tool was technically correct, we consulted two experts familiar with the topic of springs, a hydro-geologist and a hydrologist. However Aebli's approach (1983) was key to formulating the worksheet's concept and provided the basis for its conceptual design. The worksheet consists of six text-picture units that include comprehensible explanations based on the necessary conceptional depth understandable for $13 \mathrm{yr}$ old students. Only information that was essential to the comprehension of the key issues of the concept of hillslope springs such as the porosity and permeability of clastic sediments or clastic sedimentary rocks, the layered structure of the earth's crust, the existence of an aquifer outcrop at a slope, and the relationship between water input and output was included. The hydrological feature of the spring line, even though it represents a special case, was used to demonstrate the interrelation between the properties of the layers of clastic sedimentary rock in the hill and the occurrence of springs on a hillslope. Seen from the perspective of the psychology of learning the spring line serves as an anchor for the general problem to be solved in the course of the learning process.

The essential information was structured in such a way as to facilitate comprehension and correct understanding. The sketches are not drawn to scale - neither in themselves nor in relation to one another. The design decisions are underpinned by didactic considerations based on the psychology of learning, as explained below. The text-picture explanation offered in the worksheet can be characterised by three distinctive traits:

- The sequence of six text-picture units in accordance with a "question-excursus-answer" macro-structure.
- The fictitious processes in the "sandpit excursus".

- The analogy in terms of content between mountain and sandpit.

\section{1 "Question-excursus-answer" macro-structure}

The worksheet (Fig. 3) begins with a text-picture unit featuring a section of landscape in the form of a block diagram. The geological structures below the land cover are not shown in the block diagram. The same block diagram is featured again in the last text-picture unit, this time with the geological structures and hydrological situation inside the mountain visible. The hillslope spring was chosen for the technical representation of how springs are formed as it is the type of spring most likely to be readily associated with existing everyday notions (see Sect. 6). When the learner is presented with predefined information, there is always a tendency to learn in a quick, superficial way, without actively processing the information. That is why initially a comprehension-based learning attitude is to be induced here. Text-picture unit 1 is designed to give rise to a question or problem: can I explain why it is that water spills out of the mountain at certain points, which in some cases are approximately at the same level?

The learner who senses that his or her knowledge is insufficient realises that there is something astonishing going on here that requires explanation, i.e. that genuine learning in the sense of broadening one's own knowledge and understanding is required. It is only from such a learning attitude that the learner will then critically examine the information provided in the framed text-picture units 2-5 that refer to the sandpit to see whether it genuinely offers a plausible explanation for the occurrence of springs. The drawing in the textpicture unit 6 can then finally be experienced as the solution to the problem - even if this solution is presented rather than arrived at.

This problem-solving approach is in keeping with Aebli's (1983) requirements for a comprehensible explanation. Additionally, the idea to sequence the key steps or explanative idea units of the concept of freshwater springs by depicting each key step in an individual schematic illustration and to combine it with a corresponding description of the step follows the main recommendations by multimedia learning research (Mayer, 2001).

\subsection{The sandpit analogy}

Our survey of everyday ideas has shown that lay persons often have false ideas of the way in which water flows and is stored underground. In particular they have to overcome the common and evidently very obvious idea that water is stored in caves and only flows through inner "tunnels" or through cracks and gaps in the rock, which is true of the particular case of karst and heavily fractured rock. So how does one convince learners that water can be stored inside the compact 

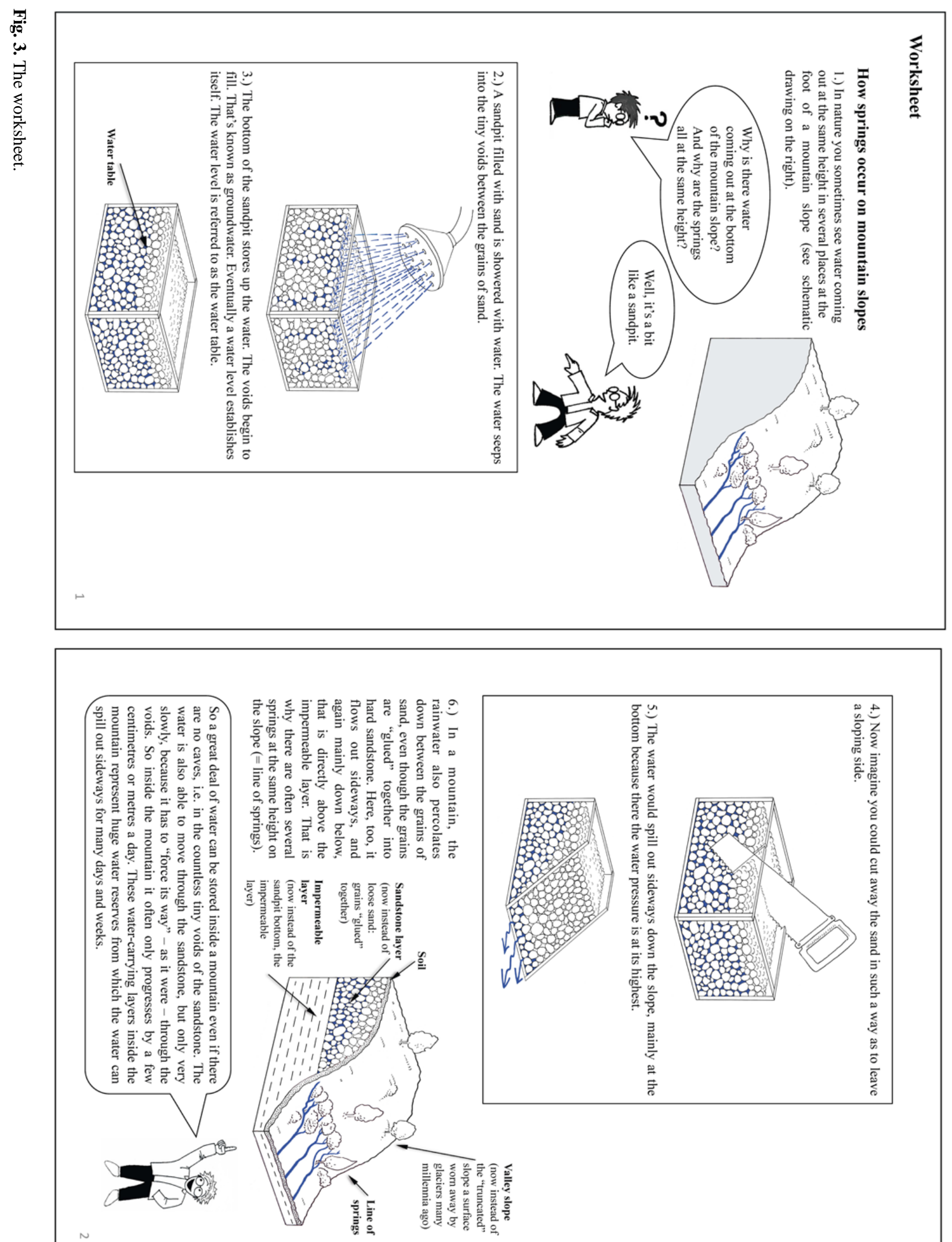
rock material itself and flow within it, and that it is not a matter of flowing through large hollow chambers in homogeneous rock but of percolating between small particles? The analogy with the sandpit is designed to help convince them of this. It brings into play the concrete childhood memory of a material capable of containing water even if it does not comprise any "caves" or "tunnels". These childhood experiences also include memories of the way in which water flows out of the side of a sandpit when you start digging a slope into the damp sand with a shovel.

\subsection{The use of fictitious states and processes}

Fictitious is of course the lateral "truncating" of the sand in the drawing of text-picture unit 4 to create a slope. Also fictitious - with regard to the situation in the real mountain - is the sequence whereby the slope in the worksheet is formed only once the water has seeped in from above. With this simulated sequence, which does not recreate the processes that occur in nature, the sandpit excursus is designed to optimise the conceptual re-traceability of the water's movement, albeit initially at the expense of scientific accuracy. The movement of the water inside the mountain is broken down conceptually into two phases: a first phase of vertical percolation (in which the water simply follows the downward pull of gravity), and a second phase of horizontal displacement (in which the water that has "arrived at the bottom" yields to the hydrostatic pressure of the water percolating and bearing down on top of it by "shifting laterally" towards the areas of least hydrostatic pressure). Both forces and both resultant directions of movement are familiar from everyday experience. By combining them, it is possible to make a convincing conceptual case explaining that the lateral outflow of the water out of the permeable stratum opened up by erosion is the result of a total displacement of water that runs through the entire material layer under the effect of the two aforementioned forces. This experience-based understanding is also preserved if one conceptually removes the artificial separation and imagines the two forces and the corresponding movements as acting simultaneously. The fact that the erosion-based events have to be brought forward in time when transposing from the sandpit model to the mountain situation (due to the fact that the permeable layer was not opened up laterally after precipitation) requires a degree of mental agility when comparing the two situations. This again promotes an active, understandingorientated learning attitude.

\section{Concluding remarks}

The hillslope spring model as illustrated in the worksheet is an explanatory model that comprises only those elements which we consider to be of relevance for lay persons when it comes to a first understanding of springs. It is not meant to fully represent the hydrological concept of hillslope springs but rather to serve as a basis for further learning. It is a childfriendly abstraction of the real circumstances aimed at reconstructing existing preconceptions of springs. Neither did we strive for completeness in a hydrological sense. From all the various spring types we picked the one example which was the most appropriate to inducing a conceptional reconstruction of the preconceptions that solid rocks are not permeable and that groundwater therefore flows in subsurface caves and veins. The scope of spring types was restricted to just one example in order to achieve a purposeful confrontation of the learners with their misconceptions which would ultimately lead to a more correct understanding of the concept of springs. The hillslope spring model as depicted in the worksheet idealises the scientific representation of a hillslope spring, which in turn is itself a model. Whether the worksheet fulfils its purpose will be verified in a video-aided learning process study in which the individual learning steps, the mental model construction and the changes in the learners' ideas are analysed step by step.

Acknowledgements. We wish to thank Eduard Hoehn (Swiss Federal Institute of Technology, Zurich), Ulrich Kattmann (University of Oldenburg), Peter Kienzler (Scherrer AG, Reinach), Daniel Küry (Life Science AG, Basel), Simon Scherrer (Scherrer AG, Reinach) and Jan Seibert (University of Zurich) for their expert and didactic advice, the teachers Karin Käppli, Roman Landolt and Martin Müller for making their classes available, and Donat Bräm (University of Teacher Education, Zurich) for drawing the illustrations in the worksheet. We also thank the anonymous reviewer and Jan C. Nonner (UNESCO-IHE) for their useful feedbacks in the interactive peer review and public discussion phase of the publication process of this paper. The research reported in this article was supported by the Swiss Mountain Water Network (Swiss Mountain Water Award 2010) and a grant (No. 13DPD3_134724/1) of the Swiss National Science Foundation.

Edited by: S. Uhlenbrook

\section{References}

Aebli, H.: Zwölf Grundformen des Lehrens. Eine Allgemeine Didaktik auf psychologischer Grundlage, Klett, Stuttgart, 1983.

Altman, D. G.: Practical statistics for medical research, Chapman and Hall, London, 1991.

Auckenthaler, A. and Huggenberger, P.: Pathogene Mikroorganismen im Grund- und Trinkwasser, Transport, Nachweismethoden, Wassermanagement, Birkhäuser, Basel, 2003.

Ausubel, D.: Educational psychology: A cognitive view, Holt, Rinehart and Winston, New York, 1968.

Bar, V.: Children's views about the water cycle, Sci. Educ., 53, 481500, 1989.

Baumgartner, A. and Liebscher, H.-J. (Eds.): Allgemeine Hydrologie, Gebr. Bornträger, Berlin, Stuttgart, 1990.

Baur, A.: Brunnen: Quellen des Lebens und der Freude, Oldenbourg Verlag, München, Wien, 1989. 
Ben-zvi-Assarf, O. and Orion, N.: A study of junior high students' perceptions of the water cycle, J. Geosci. Educ., 53, 366-373, 2005.

Brown, D. and Clement, J.: Overcoming misconceptions via analogical reasoning, Instr. Sci., 18, 237-261, 1989.

Chang, J.-Y.: Teachers college students' conception about evaporation, condensation, and boiling, Sci. Educ., 83, 511-526, 1999.

Clement, J.: Students' preconceptions in introductory mechanics, Am. J. Phys., 50, 66-70, 1982.

Denzler, L.: Wie der Klimawandel das Süsswasser verändert, Neue Zürcher Zeitung, 19 August 2009.

Dickerson, D. and Dawkins, K.: Eighth grade students' understandings of groundwater, J. Geosci. Educ., 52, 178-181, 2004.

Dickerson, D., Callahan, T. J., van Sickle, M., and Hay, G.: Students' conceptions of scale regarding groundwater, J. Geosci. Educ., 53, 374-380, 2005.

Dove, J.: Alternative conceptions about the weather, School Sci. Rev., 79, 65-69, 1998.

Dove, J. E., Everett, L. A., and Preece, P. F.: Exploring a hydrological concept through children's drawings, Int. J. Sci. Educ., 21, 485-498, 1999.

Duit, R. and Treagust, D. F.: Conceptual change: a powerful framework for improving science teaching and learning, Int. J. Sci. Educ., 25, 671-688, 2003.

Garbrecht, G.: Geschichte der Hydrologie, in: Allgemeine Hydrologie, edited by: Baumgartner, A. and Liebscher, H.-J., Gebr. Bornträger, Berlin, Stuttgart, 11-42, 1990.

Glasersfeld, E.: Cognition, construction of knowledge, and teaching, Synthese, 80, 121-140, 1989.

Göbel, P.: Quellen - Ursprung des Lebens, 1st Edn., LWLArchäologie für Westfalen, Münster, 2007.

Häussler, P., Bünder, W., Duit, R., Gräber, W., and Mayer, J.: Naturwissenschaftsdidaktische Forschung - Perspektiven für die Unterrichtspraxis, IPN, Kiel, 1998.

Hass C., Schiesser C., and Wahrenberg, A.: Das Wasserbuch, Patmos Verlag, Düsseldorf, 2004.

Hölting, B. and Coldewey, W. G.: Hydrogeologie - Einführung in die Allgemeine und Angewandte Hydrogeologie, 6th Edn., Elsevier, München, 2009.

Johnson-Laird, P. N.: Mental models, Cambridge University Press, Cambridge, UK, 1983.

Kattmann, U., Duit, R., Gropengießer, H., and Komorek, M.: Das Modell der Didaktischen Rekonstruktion - Ein Rahmen für naturwissenschaftsdidaktische Forschung und Entwicklung, Zeitschrift für die Didaktik der Naturwissenschaften, 3, 3-18, 1997.

Koechlin, S.: Prognosen für die Dusche, Horizonte Schweizer Forschungsmagazin, 90, 11-12, 2011.

Krummenacher, J.: Ein Tunnelbau entzieht dem Caumasee Wasser, Neue Zürcher Zeitung, 2007, available at: www.nzz. ch/nachrichten/schweiz/articleex772_1.112635.html (last access: 29 January 2012), 2007.

Mayer, R. E.: Multimedia Learning, Cambridge University Press, Cambridge, New York, 2001.

Mayer, R. E.: Constructivism as a theory of learning versus constructivism as a prescription for instruction, in: Constructivist Instruction. Success or Failure?, edited by: Tobias, S. and Duffy, T. M., Routledge, New York, London, 184-200, 2009.
Mayring, P.: Die Praxis der Qualitativen Inhaltsanalyse, Beltz, Weinheim, Basel, 2008.

McCloskey, M.: Naïve theories of motion., in: Mental models, edited by: Gentner, D. and Stevens, A., Lawrence Erlbaum Associates, Inc., Hillsdale, NJ, 299-324, 1983.

Messner, R. and Reusser, K.: Aeblis Didaktik auf psychologischer Grundlage im Kontext der zeitgenössischen Didaktik, in: Didaktik auf psychologischer Grundlage. Von Hans Aeblis kognitionspsychologischer Didaktik zur modernen Lehr- und Lernforschung, 1st Edn., edited by: Baer, M., Fuchs, M., Füglister, P., Reusser, K., and Wyss, H., h.e.p.-Verlag, Bern, 52-73, 2006.

Österlind, K. and Halldén, O.: Linking theory to practice: A case study of pupils' course work on freshwater pollution, Int. Res. Geogr. Environ. Educ. 16, 73-89, 2007.

Piaget, J.: Science of education and the psychology of the child, Oxford University Press, New York, 1970.

Piaget, J.: The principles of genetic epistemology; translated from the French, Basic Books, New York, 1972.

Piaget, J. and Cook, M.: Origins of intelligence in children, 6th Edn., International Universities Press, New York, 1975.

Regli, D.: Tunnelbauer wollen für Ersatz sorgen. Schadenersatzforderung wegen versiegender Wasserquellen. Urner Wochenblatt, 2009, available at: http://www.urnerwochenblatt. ch/aktuelle_ausgabe/nachrichten_details.asp?id=7198 (last access: 29 January 2012), 2009.

Reinfried, S.: Ready for the 21st Century? - The impact of curriculum reform on geography education in upper secondary schools in Switzerland, Int. Res. Geogr. Environ. Educ., 10, 421-428, 2001.

Reinfried, S.: Alltagsvorstellungen - und wie man sie verändern kann. Das Beispiel Grundwasser, Geographie heute, 27, 38-42, 2006a.

Reinfried, S.: Conceptual Change in Physical Geography and Environmental Sciences through Mental Model Building: The Example of Groundwater, Int. Res. Geogr. Environ. Educ., 15, 41-62, 2006 b.

Reinfried, S., Rottermann, B., Aeschbacher, U., and Huber, E.: Alltagsvorstellungen über den Treibhauseffekt und die globale Erwärmung verändern - eine Voraussetzung für Bildung für nachhaltige Entwicklung, Schweizerische Zeitschrift für Bildungswissenschaften, 32, 251-271, 2010.

Reinfried, S., Aeschbacher, U., and Rottermann, B.: Improving students' conceptual understanding of the greenhouse effect using theory-based learning materials that promote deep learning, Int. Res. Geogr. Environ. Educ., 21, 95-119, 2012.

Sanchez, J. L.: Ich bin ein Regentropfen, Parabel Verlag, Weinheim, 1977.

Schmid, E.: Eine Wasserreise. Der Lauf des Flusses von der Quelle bis zum Meer, Nord-Süd-Verlag, Zürich, 1989.

Shepardson, D. P., Wee, B., Priddy, M., Schellenberg, L., and Harbor, J.: Water transformation and storage in the mountains and at the coast: Midwest Students, Int. J. Sci. Educ., 31, 1147-1471, 2009.

Suter, D., Küry, D., Baltes, B., Nagel, P., and Leimgruber, W.: Kulturelle und soziale Hintergründe zu den Wahrnehmungsweisen von Wasserquellen, Mitteilungen der Naturforschenden Gesellschaften beider Basel, 10, 81-100, 2007.

Tarbuck, E. J. and Lutgens, F. K.: Earth science, Pearson Prentice Hall, Upper Saddle River, NJ, 2009. 
Vosniadou, S.: Conceptual change research: An introduction, in: International Handbook of Research on Conceptual Change, edited by: Vosniadou, S., Routledge, New York, xiii-xxviii, 2008.

Vosniadou, S., Vamvakoussi, X., and Skopeliti, I.: The framework theory approach to the problem of conceptual change, in: International Handbook of Research on Conceptual Change, edited by: Vosniadou, S., Routledge, New York, 3-34, 2008.

Vygotsky, L.: Thought and language, MIT Press, Cambridge, MA, 1962.
Vygotsky, L.: Mind in society: The development of the higher psychological processes, Harvard University Press, Cambridge, MA, 1978.

Wiesner, H.: Physikunterricht - an Schülervorstellungen und Lernschwierigkeiten orientiert, Unterrichtswissenschaften, 23, 127145, 1995.

Zollhöfer, J. M.: Spring Biotopes in Northern Switzerland: Habitat Heterogenity Zoobenthic Communities and Colonization Dynamics, ETH-Dissertation Nr. 13209, ETH Zürich, Zürich, 1999. 